\section{The cone dystrophies}

\section{Summary}

The cone dystrophies are a heterogeneous group of inherited disorders that result in dysfunction of the cone photoreceptors and sometimes their post-receptoral pathways. The major clinical features of cone dystrophy are photophobia, reduced visual acuity and abnormal colour vision. Ganzfeld electroretinography shows reduced or absent cone responses. On the basis of their natural history, the cone dystrophies may be broadly divided into two groups: stationary and progressive cone dystrophies. The stationary cone dystrophies have received more attention, and subsequently our knowledge of their molecular genetic, psychophysical and clinical characteristics is better developed. Various methods of classification have been proposed for the progressive cone dystrophies, but none is entirely satisfactory, largely because the underlying disease mechanisms are poorly understood. Multidisciplinary studies involving clinical assessment, molecular genetics, electrophysiology and psychophysics should lead to an improved understanding of the pathogenesis of these disorders.

Key words Cone, Dystrophy, Photoreceptor, Rod

There are a large number of different inherited disorders that give rise to cone dysfunction. Usually, the genetic mutations result in functional abnormalities that are confined to the eye, but there are a number of rare disorders in which the retinal dystrophy is associated with systemic abnormalities. St Albertus Magnus has been credited with the first description of cone dystrophy; this account dates from the thirteenth century. ${ }^{1}$ Cone dystrophy may be inherited as an autosomal recessive, autosomal dominant or X-linked recessive trait. There is considerable genetic heterogeneity, even within these genetic subtypes. The stationary cone dystrophies are congenital, in that the cone dysfunction is thought to be present at birth (rod photoreceptor function is normal). The progressive cone dystrophies usually present in childhood or early adult life, and patients often develop rod photoreceptor dysfunction in later life. There is, therefore, considerable overlap between the cone and cone-rod dystrophies: the majority of patients with progressive cone dystrophy develop a generalised retinal

\section{The stationary cone dystrophies}

The stationary cone dystrophies may be effectively subclassified on the basis of psychological testing. The major forms of stationary cone dystrophy are: anomalous trichromacy, dichromacy, monochromacy and oligocone trichromacy. Although the congenitally colour deficient possess a cone population that is deviant from the normal, their visual dysfunction is confined to colour vision. A full discussion of the congenital colour vision deficiencies will not be developed, and we would direct the reader to several reviews published on the subject. ${ }^{3-6}$

\section{Monochromatism}

By definition, the monochromat requires only one primary in order to match the entire visible spectrum. As we will see, many of those who are labelled as 'monochromats' do display a crude form of residual colour discrimination when tested under specific conditions. This has two unfortunate consequences. The first is that it gives rise to misnomers such as 'incomplete achromatopsia'. The second is that, because there is no recognised standard for assessing such subjects, two independent laboratories using different testing apparatus may differ in the diagnosis of identical conditions. Monochromats may be subdivided according to the type of photoreceptor(s) they retain. The distinction between some forms of monochromatism is unclear, and clarification will have to await the discovery of the underlying genetic mutations.

\section{Rod monochromatism}

Rod monochromatism is also known as $\pi$ ) monochromacy and 'complete' or 'typical' achromatopsia, and is inherited in an autosomal recessive fashion. Patients with this condition appear to display rod vision only. As a result,
M.P. Simunovic

Department of Experimental Psychology

University of Cambridge Cambridge, UK

\section{A.T. Moore}

Ophthalmology Department Addenbrooke's Hospital

Hills Road

Cambridge CB2 2QQ, UK

Tel: $+44(0) 1223216700$

Fax: $+44(0) 1223240085$

e-mail:atm22@hermes.cam.ac.uk

A.T. Moore

Moorfields Eye Hospital

City Road

London, UK 

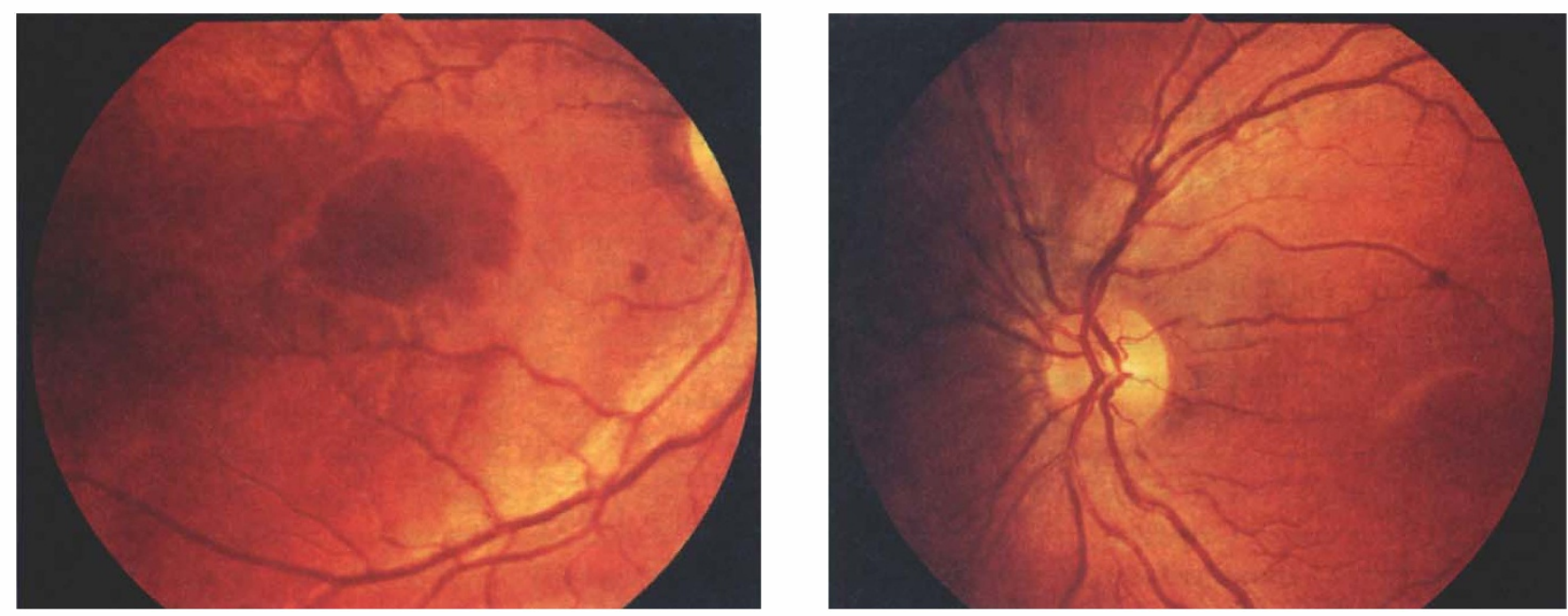

Fig. 1. Fundus photographs of a girl aged 11 years with rod monochromatism showing blunted foveal reflex.

the rod monochromat can detect only brightness differences, and is therefore truly colour-blind. ${ }^{7}$ Patients with this disorder usually present in early infancy with nystagmus, marked photophobia and reduced acuity. The nystagmus is typically of rapid frequency and low amplitude. In many cases, the nystagmus decreases in severity by the end of the first decade. Commonly, there is a high hypermetropic refractive error. In affected individuals who are old enough for accurate assessment, the visual acuity is usually about 6/60 when assessed using a standard letter chart at photopic illumination levels. A central scotoma may be demonstrated with formal perimetry, although this type of scotoma cannot be demonstrated in all patients. ${ }^{8}$ The fundus appearance of the rod monochromat is unremarkable, except that there may sometimes be a blunted foveal reflex (Fig. 1). Krill et al. ${ }^{9}$ have emphasised that if there is macular atrophy present it is likely that the patient has a progressive cone dystrophy.

Electroretinography reveals that cone responses are absent, though rod responses are normal ${ }^{2,10}$ (Fig. 2). Rod monochromats fail to recognise any plates on the common 'plate' tests (such as the Ishihara and HRR tests) and make characteristic D-15 ordering patterns, with the 'apparent axis' of confusion lying halfway between those of a tritan and a deutan. Although there is no true colour perception, patients may be able to distinguish some colours via their relative lightness.
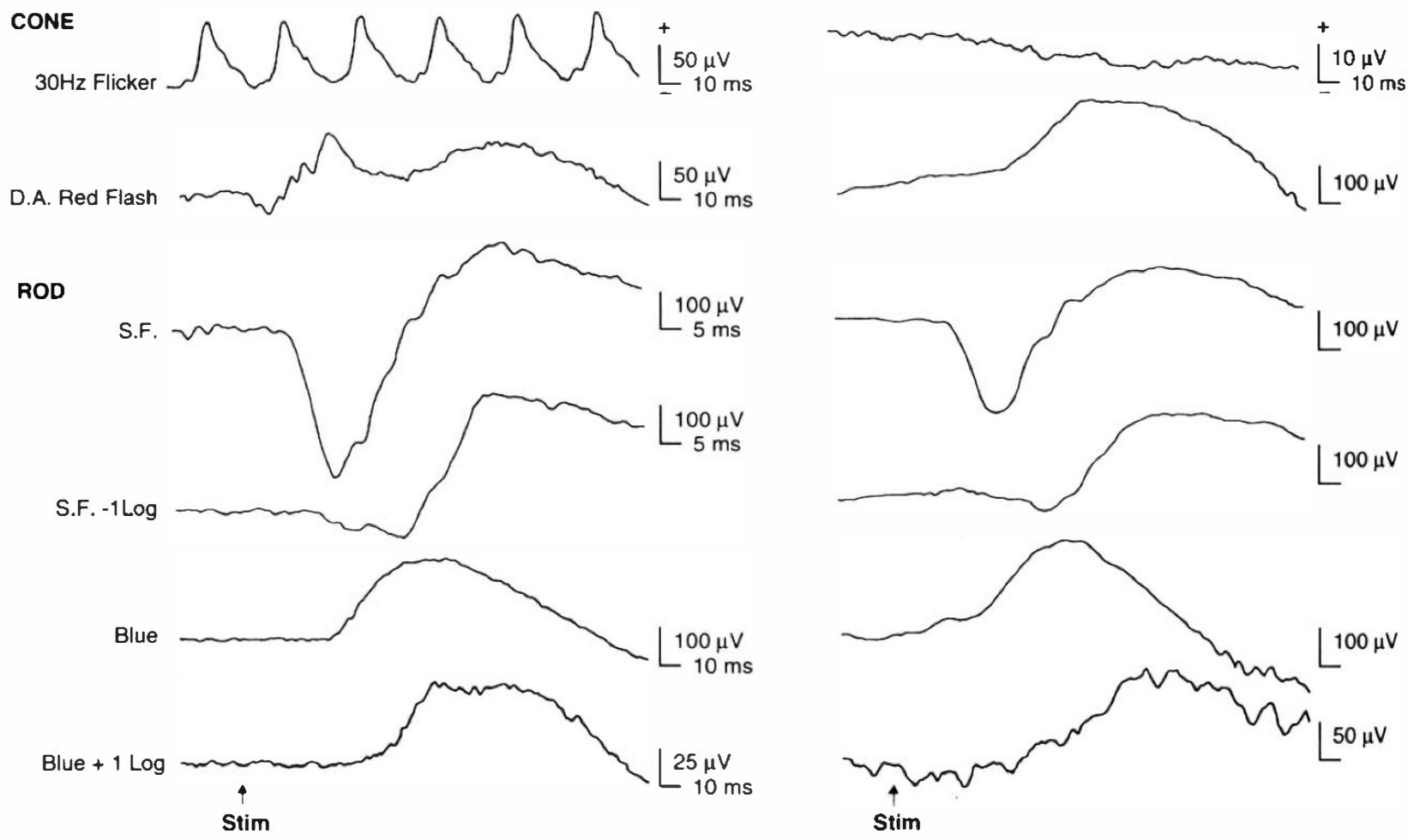

Fig. 2. The electroretinograms of a normal control subject (left) and a rod monochromat aged 11 years (right) using gold foil recording electrodes. The rod responses are normal, but there are no recordable cone responses. 
Histopathological investigation of donor eyes from subjects with rod monochromatism has demonstrated the presence of cone-like structures in the retina. ${ }^{11-14}$ However, the studies have given conflicting reports as to the nature and distribution of these cones. Larsen ${ }^{11}$ found that the cones had short outer segments with large diameters, especially around the macular area. Harrison and colleagues ${ }^{12}$ reported that the cones were abnormally shaped and reduced in number throughout the entire retina. Falls and colleagues ${ }^{13}$ found cone numbers at the fovea to be normal, but their shape to be abnormal. In the periphery the cones were scarce, though less commonly malformed. In contrast Glickstein and Heath ${ }^{14}$ found that the fovea was totally devoid of cones; those present in the surrounding area were abnormal in morphology.

Psychophysical testing may also reveal residual cone function in rod monochromats. For example, a Stiles-Crawford effect may be demonstrated, ${ }^{15}$ and the dark adaptation curve may be biphasic. ${ }^{15-19}$ Increment threshold experiments may also show a duplex function. ${ }^{20,21}$ In an extensive survey of the psychophysical literature, Sharpe and Nordby ${ }^{8}$ report that 18 out of a total of 37 investigations of rod monochromatism claim to have found psychophysical evidence of cone function. In addition, Krastel and Jaeger ${ }^{22}$ have demonstrated, using large fields, that many of those labelled as rod monochromats may have residual cone function. However, many of the studies should be treated with caution: it is possible that the investigators were describing occult cases of incomplete achromatopsia, or even progressive cone dystrophy. ${ }^{8}$

The genetic mutation responsible for rod monochromatism has not been identified, but Arbour et al..$^{23}$ have demonstrated linkage of the disorder in a large Iranian Jewish pedigree to a $30 \mathrm{cM}$ region spanning the centromere of chromosome 2. Rod monochromacy has also been reported to occur in association with isodisomy of chromosome $14 .^{24}$

Carriers of rod monochromatism are generally considered to possess normal visual function. However, it has been claimed that some carriers display subtle colour vision abnormalities. ${ }^{25,26}$

\section{Autosomal recessive incomplete achromatopsia}

As stated previously, the term 'incomplete achromatopsia' is a misnomer. This condition is also sometimes called atypical achromatopsia. The 'incomplete achromat' appears to have residual colour discrimination. ${ }^{27}$ However, in many ways this condition resembles rod monochromacy. Affected individuals may have slightly better visual acuity than the rod monochromat $(6 / 24-6 / 60)$, poor colour discrimination, nystagmus, photophobia and an absent cone electroretinogram. ${ }^{2}$ However, when tested using large field sizes at appropriate illumination levels (so that rod participation is possible), these patients display crude dichromacy or even trichromacy. Pokorny et al. ${ }^{27}$ demonstrated via colour matching experiments that there are at least four forms of achromatopsia of autosomal recessive inheritance. In type $\mathrm{I}$, there is no evidence of cone function (these patients are rod monochromats), in type II incomplete achromatopsia, colour matches are governed by rods and M-cones, in type III incomplete achromatopsia, colour matches are mediated by the L- and M-cones, and in the final form, type IV, colour matches are mediated by rods, L-cones and S-cones. It appears that type II incomplete achromatopsia corresponds to 'incomplete achromatopsia with protan luminosity'. ${ }^{28}$ It also appears that type IV incomplete achromatopsia corresponds to 'incomplete achromatopsia with deutan luminosity'. ${ }^{29,30}$ Because there are several reports of pedigrees in which both rod monochromacy and incomplete achromatopsia occur, ${ }^{26,27,31,32}$ it is likely that rod monochromatism and some forms of incomplete achromatopsia, such as type $\mathrm{II}^{27}$ may represent phenotypical variations of a single genetic defect.

\section{Blue cone monochromatism}

The blue cone monochromat possesses a normal rod system with a normal S-cone mechanism. Blue cone monochromatism is an X-linked recessive disorder, and affected males present with reduced acuity (6/24-6/60), nystagmus and photophobia. ${ }^{2}$ The condition is also sometimes known as X-linked atypical achromatopsia or $\pi_{1}$ monochromacy. Most affected individuals are myopic; fundus examination may show tilted optic discs though the macular appearance is normal (Fig. 3). Using standard ERG protocols, the abnormalities are similar to those seen in rod monochromacy (Fig. 4), but with specialised spectral electroretinographic techniques ${ }^{33}$ it is possible to differentiate between the two cone disorders. The blue monochromat may also be distinguished from the rod monochromat via psychophysical testing. Under mesopic and low photopic illumination levels, the blue cone monochromat will show dichromatic colour vision, ${ }^{34,35}$ with the neutral point lying at around $460-470$ nm. ${ }^{34}$ Hansen $^{36}$ suggests that short-wavelength specific perimetry can distinguish between blue cone and rod monochromats. It may also be possible to separate some blue cone monochromats from rod monochromats via the D-15 or the FM 100-Hue test: the blue cone monochromat may show a protan-like ordering of the D-15, and displays fewer tritan errors on the FM 100-Hue test. Sometimes, however, blue cone monochromats may behave like rod monochromats on the latter two tests. Berson et al. ${ }^{37}$ have developed a plate test that is capable of differentiating rod monochromatism from blue cone monochromatism; however, it may not successfully differentiate the latter from cases of progressive cone dystrophy. ${ }^{38}$ Smith et al. ${ }^{39}$ found evidence for residual L-cone function in blue cone monochromatism, but this finding could not be confirmed by Hess et al. ${ }^{40}$

Female carriers of blue cone monochromatism are asymptomatic, have a normal fundus and normal visual acuity, but may show abnormal cone electroretinogram 

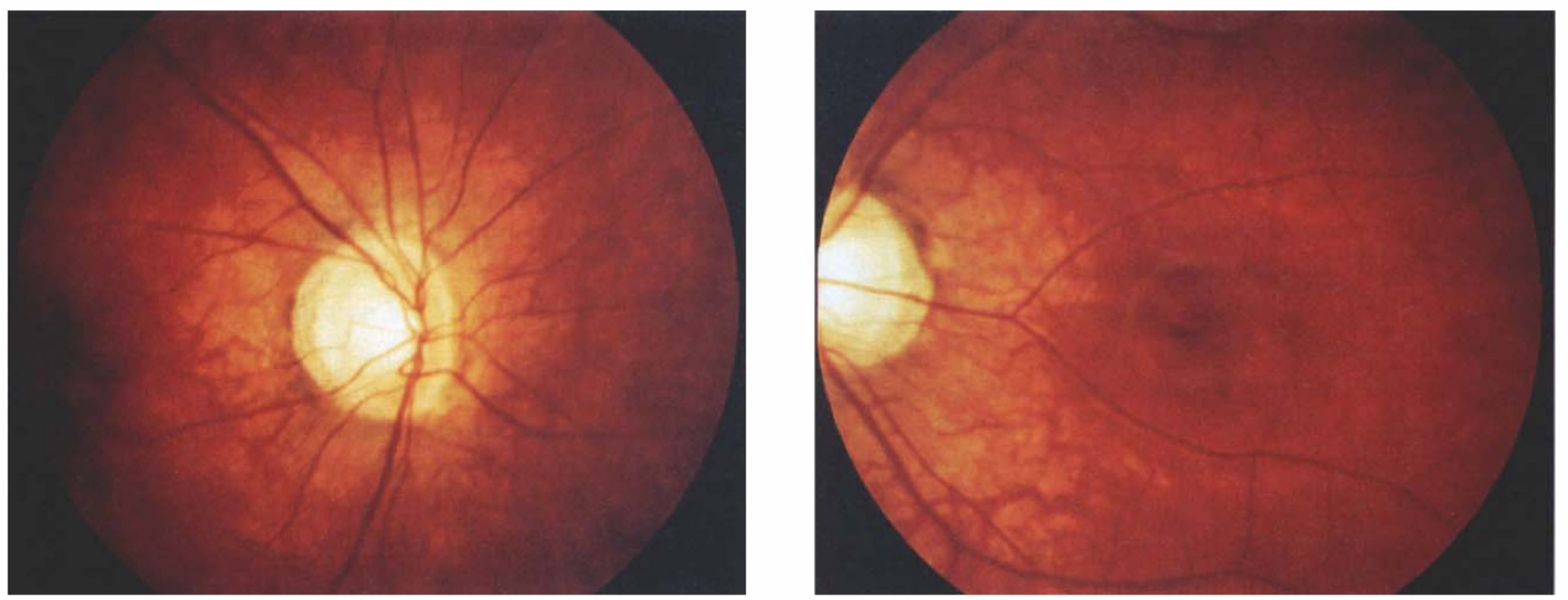

Fig. 3. Fundus photographs of a boy aged 10 years with blue cone monochromatism showing tilted optic disc and blunted foveal reflex.

responses $^{37,41}$ and mild abnormalities of colour vision; ${ }^{9}$ they may also show abnormalities on eye movement recording. $^{42}$

Nathans and his colleagues ${ }^{43}$ were the first to investigate in detail the molecular genetics of blue cone monochromatism. The defects in their patients could be divided into two distinct subtypes. In the first, there is a two-step mechanism: the L- and M-cone photopigment array is reduced to a single gene by unequal homologous recombination; a further mutation renders the remaining gene defective. In one of the original 12 families studied, there was a remaining L-cone photopigment gene, and in another three there was a 5' L-3' $\mathrm{M}$ hybrid gene. Cloning of the hybrid genes revealed a cysteine to arginine mutation at codon 203. This mutation is known to disrupt the folding and half-life of $\mathrm{M}$-cone opsin molecules. ${ }^{44}$ The second mechanism consists of a nonhomologous deletion of genetic material upstream of, and sometimes including, the pigment gene array. The deletion sizes ranged from $587 \mathrm{bp}$ to $55 \mathrm{~kb}$. All the deletions included the $587 \mathrm{bp}$ region missing in patients with the smallest deletion. This region lies $3 \mathrm{~kb}$ upstream of the opsin gene array, and is believed to act as transcriptional control element. The region is commonly referred to as the locus control region (LCR). In a second study of the condition, Nathans et al. ${ }^{45}$ reported further genetic heterogeneity in the condition. This study includes one family in which there are two photopigment
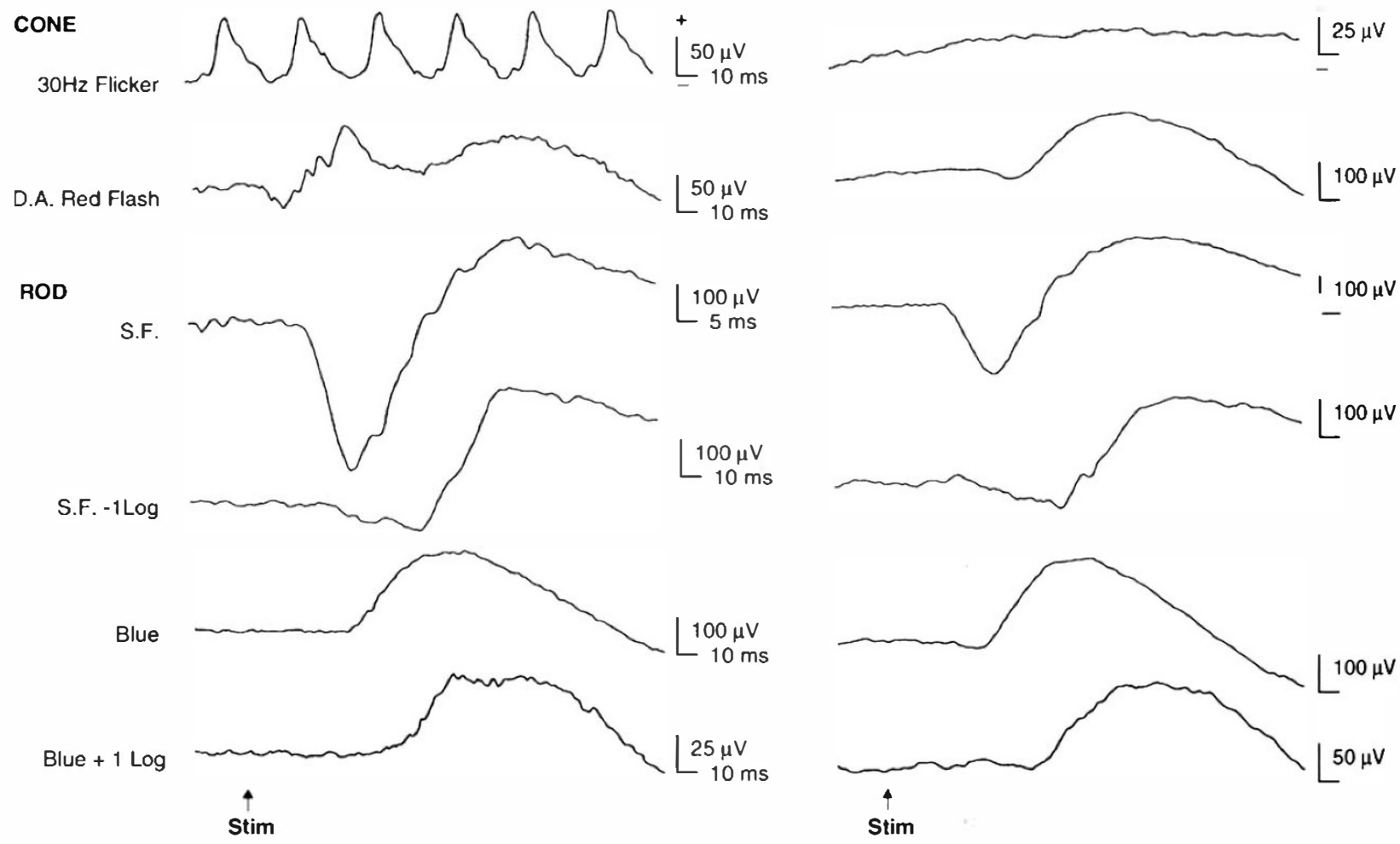

Fig. 4. Electroretinogram of a control subject (left) and a boy aged 10 years with blue cone monochromatism (right) recorded under identical conditions to Fig. 2. There are no recordable cone responses. 
genes containing mutations in codon $203 .{ }^{45}$ Reyniers et al. ${ }^{46}$ have reported a pedigree with a similar genetic defect. Recently, a pedigree has been reported where affected patients have one L-cone photopigment gene in which exon 4 is deleted. ${ }^{47}$

It appears there may be some degree of overlap between blue cone monochromacy and X-linked progressive cone dystrophy (see below). For example, Nathans et al. ${ }^{43}$ reported a subject in which a very slow degeneration is apparent, and Nathans et al. ${ }^{45}$ reported the molecular genetic findings of a family previously described in a paper by Fleischman and O'Donnell. ${ }^{48}$ This family appeared to display a progressive dystrophy; older members of the pedigree demonstrated achromatopsia with severely reduced acuity, whereas younger members had markedly lower FM 100-Hue scores together with better acuity; the older patients also showed noticeable fundus changes. These patients also had mildly reduced scotopic electroretinographic responses. Previous reports by Blackwell and Blackwell ${ }^{18}$ and Francois et al. ${ }^{49}$ had hinted at the possibility that blue cone monochromacy may progress to resemble rod monochromacy. Interestingly, the pedigree described by Francois et al. ${ }^{49}$ is the same as the family in the molecular genetic study of the condition by Reyniers et al. ${ }^{46}$

Although it appears that in the majority of families the condition is stationary, there is convincing evidence to suggest that progression does occur in other pedigrees. The pedigree described by Fleischman and O'Donnell ${ }^{48}$ would certainly be better described as having a progressive cone dystrophy.

\section{Achromatopsia with normal visual acuity}

Achromatopsia with normal visual acuity is extremely rare, affecting approximately 1 in every 100 million people. ${ }^{50}$ Affected individuals are monochromats, though they have normal visual acuity, and it appears that these conditions are not purely receptoral; therefore, strictly speaking these conditions are not cone dystrophies. One case of achromatopsia with normal visual acuity, from an original cohort of three assembled by Weale in $1953,{ }^{51}$ was also studied by Fincham, ${ }^{52}$ Gibson, ${ }^{53}$ Ikeda and Ripps ${ }^{54}$ and again by Weale in 1959. ${ }^{55}$ Pitt $^{56}$ has also described a similar patient. The three subjects studied originally by Weale had a reduction in sensitivity for long wavelengths; as a result, this form of achromatopsia with normal acuity has been referred to as the 'protan type' by Jaeger ${ }^{57}$ and Pokorny et al. ${ }^{50}$ Fincham ${ }^{52}$ demonstrated that the same three subjects could use cues gained from the chromatic aberrations of the eye's focusing system as a cue for altering accommodation. One of the subjects, A.B., was further studied by Weale in 1959; retinal densitometry revealed a normal photopigment complement. ${ }^{55}$ Central increment threshold testing of the same patient revealed normal Stiles $\pi$ mechanisms. ${ }^{53}$ Ikeda and Ripps ${ }^{54}$ found that the electroretinographic (b-wave) spectral sensitivity of this patient corresponded reasonably well with that measured psychophysically (there was a decreased sensitivity for long wavelengths). These authors compared the defect with that observed in congenital stationary night blindness, where scotopic electroretinographic abnormalities occur, even though the rhodopsin complement appears to be normal. The evidence gained by Weale, Fincham and Gibson seems to be in good agreement; all the observations point to a post-receptoral defect.

Alpern ${ }^{58}$ has reported a case of monochromacy with normal visual acuity in which the subject displayed monochromacy and a normal luminosity function in combination with normal acuity. This type of achromatopsia has been referred to as the 'deuteranopic form' ${ }^{57}$ Reflectometry revealed that there was only one cone visual pigment in the 'red-green range', though a $\pi 1$ function could be demonstrated, indicating that there was a combination of a photopigment and a postreceptoral defect.

Cases of monochromacy with normal visual acuity have been reported in pedigrees carrying multiple forms of colour vision deficiency; $C_{\text {rone }}{ }^{59}$ reported a pedigree in which tritan and deutan defects occur. Whilst two patients were believed to have achromatopsia, two also appeared to have what Crone described as 'colour amblyopia'. These patients had normal acuity but very poor colour discrimination. Weale ${ }^{51}$ reported that one of his monochromats, J.G., had a protanomalous father and a protanomalous son.

\section{Oligocone trichromacy}

Oligocone trichromacy is a stationary cone dystrophy first recognised by van $\mathrm{Lith}^{60}$ in which the affected patient displays reduced visual acuity, a reduced photopic electroretinogram and a normal fundus appearance. However, these patients are trichromats ${ }^{60}$ and they may show good colour discrimination. Reflection densitometry reveals that there is a decreased photopigment concentration, though regeneration rates appear to be normal. ${ }^{61}$ It has been proposed that oligocone trichromacy results from a reduced cone population for all cone types. ${ }^{62}$ What remains unclear is whether these patients should be grouped with incomplete achromats: for example one of the patients investigated by Pokorny and colleagues ${ }^{27}$ in their study of autosomal recessive incomplete achromatopsia had previously been classified as having oligocone trichromacy.

\section{Progressive cone dystrophies}

The progressive cone dystrophies are a genetically heterogeneous group of disorders characterised by early deterioration of visual acuity and colour vision. Other clinical features include photophobia, nystagmus and visual field abnormalities. Visual field defects include central scotomata, ${ }^{9,63}$ peripheral field loss, ${ }^{9}$ generalised depression of sensitivity ${ }^{63,64}$ and ring scotomata. ${ }^{65}$ 
Fundus examination usually shows a 'bull's eye maculopathy', but in the later stages there may be peripheral atrophy and pigmentation (Fig. 5). Other reported findings include white flecks at the level of the retinal pigment epithelium (RPE) $)^{9,66}$ and a tapetum-like sheen. ${ }^{63,67}$ Fluorescein angiography usually shows hyperfluorescence at the macula due to underlying RPE atrophy and the so-called dark choroid sign is commonly seen. Although in the early stages the ophthalmoscopic abnormality is usually confined to the macula there is psychophysical and electrophysiological evidence of widespread cone dysfunction. ${ }^{2,68}$

A distinction is sometimes drawn between cone and cone-rod dystrophies. Patients with pure cone dystrophy have a normal rod function; in contrast, those with cone-rod dystrophy have a concomitant (less severe) rod dysfunction. In many patients described as having a pure cone dystrophy, rod function is normal early in the course of the disease but deteriorates as the disease progresses; in some cases this deterioration may be profound. ${ }^{9}$ Most progressive cone dystrophies would, therefore, be more correctly described as cone-rod dystrophies.

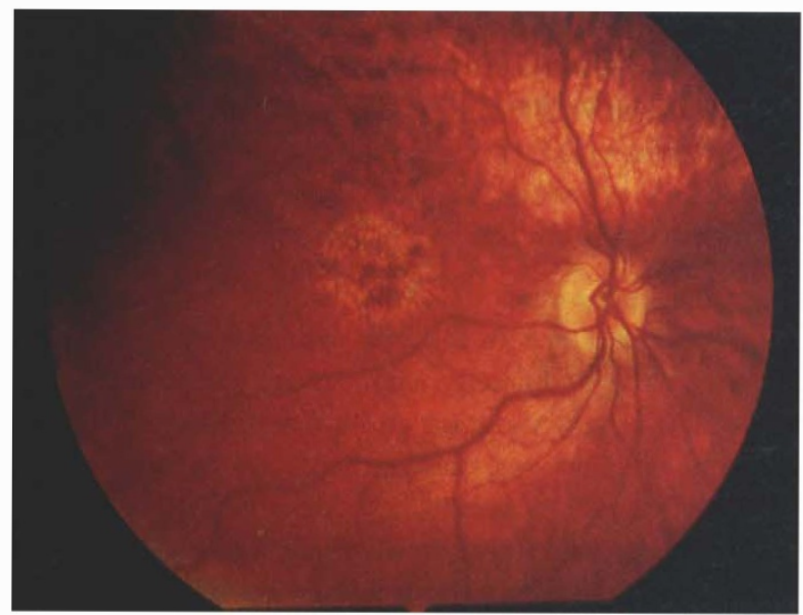

(a)

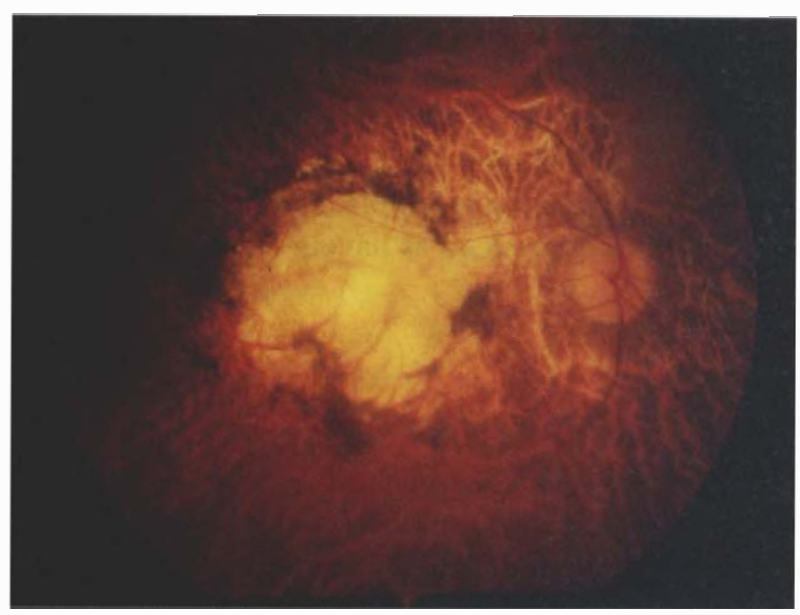

(b)
Progressive cone and cone-rod dystrophies may be inherited as autosomal recessive, autosomal dominant or $\mathrm{X}$-linked recessive traits, though most cases are sporadic. When an inheritance pattern can be firmly established, the most common inheritance observed is autosomal dominant. ${ }^{9,68}$

\section{Classification of the progressive cone dystrophies}

There are clearly many different forms of progressive cone and cone-rod dystrophy, and various methods for classifying the disorders have been proposed based on the patterns of clinical disease or on the basis of psychophysical and electrophysiological testing. None is entirely satisfactory, and a clear understanding of the disease mechanisms will have to await identification of the underlying genetic mutations.

\section{Classification on the basis of psychophysical testing}

Psychophysical testing of colour vision and the visual field have been used to investigate whether specific patterns of photoreceptor dysfunction occur in retinal
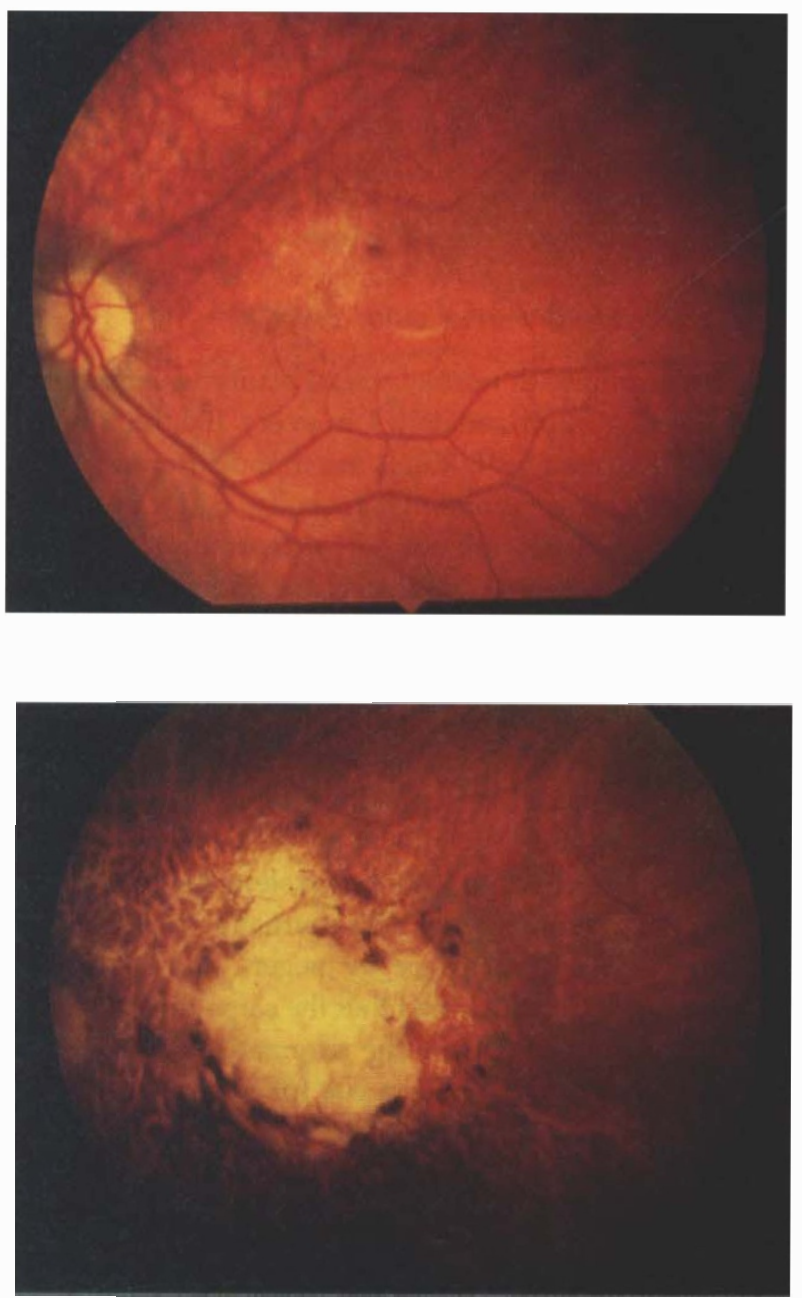

Fig. 5. (a) Fundus photographs of a man aged 22 years with a progressive cone-rod dystrophy and (b) his 60-year-old father who shows more extensive disease. 
dystrophies. These techniques are most useful in investigating large families with many affected individuals (when a specific pattern of disease can be seen to segregate clearly with the genetic mutation). Such techniques are also most informative in subjects with early or mild disease; in advanced disease, any differences between different phenotypes are usually unrecognisable due to the severe photoreceptor dysfunction.

\section{Colour vision}

A variety of colour vision deficiencies occur in progressive cone dystrophies. These include protanopia, ${ }^{69,70}$ protanomaly, pseudoprotanomaly, ${ }^{71}$ type II acquired ${ }^{67^{*}}$ and tritan defects. ${ }^{73-76}$ Pokorny et al..$^{50}$ suggested a classification of progressive cone dystrophy based upon colour vision. Three groups could be differentiated, as described below:

Cone dystrophy and type I acquired red-green defect These patients have both a progressive cone dystrophy and evidence of pseudoprotanomaly. ${ }^{50}$ Pseudoprotanomaly is diagnosed when a subject requires more red in the red-green mixture when performing a Rayleigh match than is required by a normal observer, though brightness matches are normal. This form of colour vision defect is thought to be the result of a reduction in the effective optical density of the photopigment, be it through photoreceptor tilt or decreased concentration of the photopigment. ${ }^{50}$ In the late stages of the condition, scotopisation is observed (where visual function is dominated by the rod system).

\section{Cone dystrophy without type I acquired red-green defect} Patients with abnormal photopic ERGs may appear to have no significant impairment in colour vision, or only a very slight tritan defect.

Type I acquired red-green defect without cone dysfunction In some patients with all the signs and symptoms of progressive cone dystrophy, there may be a pronounced type I acquired colour vision deficiency in the absence of an abnormal photopic electroretinogram. Such patients are usually said to suffer from a central cone dystrophy.

Unfortunately, some cone dystrophies will not be easily categorised into one of the above groups. For example, pedigrees with classical tritan defects have

${ }^{*}$ Verriest ${ }^{72}$ has classified acquired colour vision deficiencies into three groups. A type I acquired colour vision deficiency is characterised by a red-green defect with a reduction in visual acuity. This type of defect is also accompanied by an alteration in relative spectral sensitivity, which eventually becomes scotopic (so-called scotopisation). A type II acquired colour vision deficiency is a red-green defect that is often combined with a milder tritan defect; the luminosity curve is usually normal. A type IIl deficiency is a tritan defect in which the luminosity curve may be normal or abnormal. been reported. ${ }^{73-76}$ In addition, patients suffering from cone dystrophy without type I acquired defect could appear to have a colour vision deficiency if colour visual fields were assessed; similarly, those exhibiting type I acquired defect without cone dysfunction might be expected to display electroretinographic abnormalities if focal electroretinograms were performed.

\section{Other psychophysical testing}

Scotopic and photopic perimetry $\dagger$ have been used (often in combination with electrophysiological testing) to identify particular patterns of disease. ${ }^{77-81}$ Using such techniques it is possible to distinguish those individuals with a pure cone dystrophy from those with a concomitant rod involvement; the latter, as expected, have a poorer visual prognosis. A further dichotomy is revealed by such testing: in some patients there is regional loss of cone function, whereas in others there is a diffuse loss of cone function. ${ }^{78-80}$ Szlyk et al..$^{80}$ have proposed a classification of progressive cone-rod dystrophy based upon electroretinography and perimetry. One may distinguish those dystrophies that cause a marked reduction of photopic function with little effect on the scotopic function from those that affect both systems markedly (types one and two respectively). A further subdivision is provided by perimetry: in type ' $a$ ' there are central field defects whilst in type ' $b$ ' there is predominantly peripheral visual field loss. Yagasaki and Jacobsen ${ }^{77}$ have used scotopic static perimetry to define three patterns of cone and rod dysfunction. These patterns show some overlap with the classification of Szlyk et al.

Although different test protocols have been used in the different psychophysical studies, it does appear that progressive cone dystrophies may be divided into those that result in abnormal cone function without rod involvement and those with evidence of dysfunction of both types of receptor. Both subgroups can be further subdivided on the basis of whether there is predominantly central cone involvement or diffuse elevation of cone thresholds throughout the retina. There is also some evidence to suggest that there is a significant post-receptoral defect in some families. ${ }^{82,83}$

\section{Electroretinography}

In some respects, electroretinographic classification corresponds to that obtained via visual field analysis. Most individuals with progressive cone dystrophy show severely reduced cone responses with preserved rod function (at least in the early stages). However, some

$\dagger$ Scotopic and photopic perimetry are also often termed 'rod-' and 'cone-' perimetry respectively. Scotopic perimetry usually involves standard static perimetry protocols, though the patient is dark-adapted. Large (Goldman size V) short wavelength targets are typically used. Photopic perimetry requires a background set to photopic levels (typically $10 \mathrm{~cd} / \mathrm{m}^{2}$ ). The stimuli are usually of long wavelength. 
patients appear to display normal or near normal electroretinograms in the presence of all the other signs and symptoms of cone dystrophy. Such patients are said to suffer from a peripheral cone dystrophy. A minority of patients show other distinct electroretinographic abnormalities that may help identify subgroups with a specific underlying pathology. For example, a small subgroup of patients with cone dystrophy may show supranormal scotopic responses. ${ }^{84,85}$ Fujii et al. ${ }^{86}$ have described a family with autosomal dominant cone-rod dystrophy in which the earliest abnormality was a 'negative wave' configuration, suggesting that there is significant inner retinal dysfunction. Kellner et al. ${ }^{87}$ have also described cone dystrophy patients with negative electroretinograms.

\section{Mode of inheritance}

The most straightforward way of classifying the progressive cone dystrophies is by the inheritance pattern; there is, however, considerable heterogeneity even within each genetic subtype. A summary of the known loci for progressive and stationary cone dystrophies is given in Table 1. It is unclear how many different genetic mutations cause cone dystrophy.

\section{X-linked recessive progressive cone dystrophy}

$\mathrm{X}$-linked cone dystrophy is uncommon, though several well-documented families have been reported. ${ }^{48,63,67,69,71,88-91}$ It is evident from the clinical descriptions of these families that, although the earliest symptoms and signs are related to cone dysfunction, there is rod dysfunction late in the disease; therefore these disorders are more correctly classified as cone-rod dystrophies. Affected males are often myopic, and usually present with subnormal acuity and colour vision deficiency. A tapetum-like sheen that diminishes with dark adaptation (the so-called Mizuo phenomenon) has been reported in affected males from some families. ${ }^{63,67}$
In most reports there is early involvement of central cones with later diffuse involvement. In contrast, the family reported by Pinckers and Timmerman ${ }^{92}$ showed early involvement of peripheral cones. Carrier females are usually asymptomatic but can sometimes be identified by subnormal electroretinographic responses or subtle anomalies of colour vision. In the family studied by van Everdingen et al., ${ }^{71}$ for example, $87 \%$ of obligate heterozygotes exhibited pseudoprotanomaly. The majority of carriers also showed reduced cone photopigment density on foveal densitometry.

X-linked progressive cone dystrophy has been mapped using genetic linkage studies to three loci: Xp21-p11.1 (COD1), ${ }^{88}$ Xq27 (COD2) ${ }^{91}$ and to Xq28 (not assigned). ${ }^{69}$ Although few families are available for comparison, there are clear differences in the phenotypes of families mapping to the diferent loci. Reichel et al. ${ }^{69}$ have described a pedigree in which progressive cone dystrophy is accompanied by a protanopic colour vision deficiency. Molecular analysis of the L-cone photopigment revealed a $6.5 \mathrm{~kb}$ deletion. More recently, Kellner et al. ${ }^{70}$ reported two patients with no family history of cone dystrophy. The patients, like those of Reichel, displayed a protan colour vision deficiency; screening of the photopigment array revealed that one patient had only one L-M hybrid gene, whilst the other had both an L-M hybrid gene and a normal $\mathrm{M}$ pigment gene. Such genetic alterations usually result in congenital colour vision deficiency. ${ }^{6,70}$ Why such a genotype might give rise to a progressive cone dystrophy remains unclear. It should also be added that Kellner et al. could not rule out the possibility that the patients they investigated were protans who happened to develop a progressive cone dystrophy.

Meire et al. ${ }^{88}$ reported linkage to Xp21-11.1 (COD1) in the pedigree they investigated. Affected patients were myopic, had impaired colour vision leading to achromatopsia in older subjects, progressively impaired visual acuity and abnormal photopic electroretinograms. The electro-oculogram was also abnormal. Visual field

Table 1. Cone and cone-rod dystrophies with known chromosomal loci

\begin{tabular}{|c|c|c|c|}
\hline Chromosomal location & Phenotype & Inheritance & Reference \\
\hline $\mathrm{Xq} 28$ & Congenital red-green colour deficiencies & X-linked & Nathans et al. (1986) ${ }^{117}$ \\
\hline $\mathrm{Xq} 28$ & Blue cone monochromatism & X-linked & Nathans et al. (1989) \\
\hline $\mathrm{Xq} 28$ & Progressive cone dystrophy & X-linked & Reichel et al. $(1989)^{69}$ \\
\hline $\mathrm{Xg} 27$ & Progressive cone dystrophy & X-linked & Bergen and Pinckers (1977) $)^{91}$ \\
\hline Xp21-p11.1 & Progressive cone dystrophy & X-linked & Meire et al. $(1994)^{88}$ \\
\hline 2 & Rod monochromatism & AR & Arbour et al. $(1997)^{23}$ \\
\hline $6 \mathrm{p} 21.1$ & Progressive cone dystrophy & $\mathrm{AD}$ & Payne et al. (in press) ${ }^{105}$ \\
\hline \multirow[t]{4}{*}{$6 \mathrm{p}$} & Progressive CRD & $\mathrm{AD}$ & Jacobson et al. $(1994)^{97}$ \\
\hline & & & Nakazawa et al. $(1996)^{98}$ \\
\hline & & & Nakazawa et al. (1996) ${ }^{99}$ \\
\hline & & & Fishman et al. (1997) \\
\hline $6 q 25-q 26$ & Progressive cone dystrophy & Sporadic & Tranebjaberg et al. (1986) ${ }^{118}$ \\
\hline $7 q 22-q$ ter & Tritanopia & $\mathrm{AD}$ & Weitz et al. $(1992)^{119,120}$ \\
\hline $17 \mathrm{p}$ & Progressive cone dystrophy & $\mathrm{AD}$ & Small et al. $(1996)^{104}$ \\
\hline $17 \mathrm{p}$ & Progressive CRD & $\mathrm{AD}$ & Kellsell et al. (1997) ${ }^{96}$ \\
\hline $17 \mathrm{q} 11$ & Progressive CRD & Sporadic & Klystra et al. (1993) \\
\hline $18 \mathrm{q} 21$ & Progressive CRD & Sporadic & Warburg et al. (1991) \\
\hline $19 \mathrm{q} 13$ & Progressive CRD & $\mathrm{AD}$ & Freund et al. $(1997)^{106}$ \\
\hline
\end{tabular}

$\mathrm{CRD}$, Cone-rod dystrophy; $\mathrm{AR}$, autosomal recessive; $\mathrm{AD}$, autosomal dominant. 
testing showed central scotomata, and the dark adaptation curve was monophasic, with no observable cone contribution. Recently Bergen and Pinckers ${ }^{41}$ have described linkage to $\mathrm{Xq} 27$ (COD2) in a further pedigree with a progressive cone dystrophy. Although there are many similarities with the family described by Meire et al. ${ }^{88}$ the dystrophic process affects peripheral cones more than central cones in the early stages.

\section{Autosomal dominant progressize cone and cone-rod dystrophly}

Several genomic loci have been implicated in the aetiology of autosomal dominant progressive cone-rod dystrophy (CRD). The disorder has been mapped to chromosome $19 \mathrm{q} 13.3,{ }^{9,3.95} 17 \mathrm{q} 12-\mathrm{p} 13^{96}$ and has also been associated with a number of mutations of the peripherin/RDS gene on chromosome 6p." ${ }^{(10)}$ In addition, two sporadic cases of CRD have been reported - the first in association with a cytogenetically visible deletion of $18 \mathrm{q} 211^{101}$ and the second in association with neurofibromatosis type 1 - suggesting that there may be a further locus for CRD on chromosome $17 \mathrm{p} .{ }^{112} \mathrm{~A}$ dominant progressive cone dystrophy gene has also been mapped to chromosome 17p12-p13. ${ }^{113,1114}$ Recently, autosomal dominant progressive cone dystrophy has also been found to be associated with a mutation of the guanylyl cyclase activating protein 1 (GCAP 1) gene on chromosome 6 p21.1 in one pedigree. ${ }^{105}$ GCAP1 is a $\mathrm{Ca}^{2+}$-sensitive activator that is responsible for activating particulate guanylyl cyclase (RetGC) which in turn resynthesises cGMP. ${ }^{105}$

To date, mutations of four different genes - the peripherin/RDS gene on chromosome $6 \mathrm{p},{ }^{97-1(1)}$ the CRX gene on $19 q,{ }^{106}$ the retinal guanylate cyclase (RET-GC1) gene on chromosome $17 p^{1117}$ and the GCAP1 gene on $6 p$ $21.1^{105}$ - have been identified as causing autosomal dominant progressive cone/cone-rod dystrophy.

Mutations of peripherin / RDS have been reported in a wide variety of dominantly inherited retinal dystrophies including retinitis pigmentosa, macular dystrophies and CRDs. Peripherin/RDS is a photoreceptor-specific glycoprotein that is present in both rod and cone outer segments; mutations of the gene would be expected to affect the function of both types of photoreceptor. Mutations associated with CRD include Ser27Phe, ${ }^{100}$ Tyr184Ser, ${ }^{98}$ Asn244His, ${ }^{98}$ Asn244Lys, ${ }^{108}$ Val200Glu, ${ }^{49}$ Met67del ${ }^{97}$ and Lys193del. ${ }^{97}$ The reported phenotypes associated with peripherin/RDS mutations are, with the exception of the family described by Fishman et al., ${ }^{100}$ of a relatively severe CRD with early macular atrophy and later peripheral retinal atrophy. A diverse range of retinal phenotypes result from mutations of the peripherin/RDS gene, and the reasons why different mutations have such a variable effect on retinal function is poorly understood.

The CRD linked to chromosome $19 q$ results in a relatively severe phenotype. Loss of visual acuity occurs in the first decade and night blindness develops in the third decade, progressing to severe loss of visual function by age 50 years. ${ }^{95}$ By contrast, the CRD associated with chromosome 17p12-p13 has a much milder phenotype with better preserved rod function. Recently the genetic mutations underlying these two retinal dystrophies have been identified. Freund et al. ${ }^{106}$ have demonstrated that mutations in a novel photoreceptor-specific homeodomain transcription factor gene (CRX) give rise to an autosomal dominant form of CRD linked to the CORD2 locus on chromosome 19q13 in one large family and in a second smaller family with a similar phenotype. The chromosome $19 \mathrm{q}$ mutation in the original family described by Evans et al. has yet to be identified (K. Evans, personal communication). At present little is known about the function of the CRX protein product, but it is believed to be important for maintenance of photoreceptor outer segment structure. Kelsell et al. ${ }^{10 /}$ have recently identified two dominant missense mutations in the retinal guanylate cyclase (RETGC1) gene on chromosome 17p in four families with autosomal dominant CRD. Homozygous mutations of this gene had already been identified as a cause of infantile rod-cone dystrophy (Leber's amaurosis) by Perrault et al. ${ }^{1(1)}$ It is improbable that simple haploinsufficiency could account for CRD phenotype; it is likely that mutations behave in a dominant negative fashion, interfering with normal function of RET-GC. Mutations of RET-GC give rise to a mixed photoreceptor dystrophy, whereas mutations in GCAP1 are associated with a pure cone dystrophy.

Went and colleagues ${ }^{\text {it }}$ have investigated a pedigree with a dominantly inherited cone dystrophy that is characterised by the early onset of a tritan colour vision deficiency. Candidate analysis of the S-cone photopigment, however, failed to find evidence of abnormality.

Mutations of other genes responsible for CRD remain to be discovered. These will be identified either by initial linkage studies in large families, followed by analysis of candidate genes mapping to the same loci, or by the study of genes which seem to be good candidates based upon careful investigation of the phenotype in smaller families.

\section{Autosomal recessize cone dystrophy}

Most patients with cone dystrophy or CRD have no affected relatives, and it is likely that many have autosomal recessive disease. In contrast to $\mathrm{X}$-linked and autosomal dominant forms of the disorder, there is little documentation on the phenotype of individuals with cone dystrophy in whom there is a family history compatible with recessive disease. It is likely, however, that autosomal recessive cone dystrophy is genetically heterogeneous. Most of the syndromes in which cone dystrophy is associated with other systemic abnormalities display autosomal recessive inheritance (Table 2). 
Table 2. Syndromes with associated cone or cone-rod dystrophy (CRD)

\begin{tabular}{|c|c|c|c|c|}
\hline Syndrome & Inheritance & Ocular phenotype & Systemic phenotype & Reference \\
\hline Bardet-Biedl syndrome & $\mathrm{AD}$ & CRD, myopia & $\begin{array}{l}\text { Polydactyly, obesity, variable } \\
\text { mental retardation, hypogonadism }\end{array}$ & Kwiteck-Black et al. (1993) ${ }^{110}$ \\
\hline Alström's syndrome & AR & Early-onset CRD & $\begin{array}{l}\text { Diabetes, obesity, deafness, other } \\
\text { endocrine abnormalities }\end{array}$ & Michaud et al. $(1996)^{121}$ \\
\hline $\begin{array}{l}\text { Pierre-Marie ataxia and } \\
\text { CRD }\end{array}$ & $\mathrm{AD}$ & CRD & Ataxia & Bjork et al. $(1956)^{122}$ \\
\hline $\begin{array}{l}\text { Amelogenesis imperfecta } \\
\text { and CRD }\end{array}$ & AR & Early-onset CRD & Defective tooth enamel & Jalili et al. $(1988)^{123}$ \\
\hline $\begin{array}{l}\text { Obesity, cardiomyopathy } \\
\text { and retinal dystrophy }\end{array}$ & AR & Early-onset CRD & Obesity, cardiomyopathy & Russell-Eggitt et al. (1989) ${ }^{124}$ \\
\hline $\begin{array}{l}\text { Liver disease and cone } \\
\text { dystrophy }\end{array}$ & AR & Early-onset CRD & $\begin{array}{l}\text { Liver disease, endocrine } \\
\text { dysfunction, hearing defects }\end{array}$ & Hansen et al. $(1976)^{125}$ \\
\hline Trichomegaly and CRD & AR & Early-onset CRD & Enlarged lashes, excessive body hair & Jalili et al. (1988) \\
\hline
\end{tabular}

$\mathrm{AR}$, autosomal recessive; $\mathrm{AD}$, autosomal dominant.

\section{Cone and cone-rod dystrophies in systemic disease}

Most patients with cone dystrophy have no other systemic abnormalities, but there are a few rare disorders in which the underlying genetic mutation results in a cone dystrophy or CRD in association with other systemic abnormalities (Table 2). Most of these disorders are inherited as autosomal recessive traits, and in the majority, the retinal dystrophy is of early onset and has a poor visual prognosis. None of the causative genes have been identified, although the Bardet-Biedl syndrome has been mapped to chromosomes $16 q,{ }^{110} 11 q,{ }^{111} 3 q,{ }^{112}$ and 15q. ${ }^{13}$

\section{Management}

There is as yet no specific treatment for any of the cone dystrophies. However, it is very important that the correct diagnosis is made so that affected individuals and their parents can be offered genetic counselling, including accurate information about the long-term visual prognosis. The diagnosis of an inherited retinal dystrophy in one member of a family may have implications for other asymptomatic family members, particularly for females in X-linked pedigrees, and counselling may need to involve the wider family. In some families where the genetic mutation is known or the disorder has been closely mapped, molecular genetic diagnosis may be possible in cases where there is doubt about the genetic status of an individual.

Patients with poor central vision should be referred for assessment for low visual aids and, where appropriate, for advice about help with their education. Adults and children with severe photophobia may be helped by tinted spectacles or contact lenses. The tints used depend on the type of dystrophy. For example, the rod monochromat is best served by using a deep red tint; ${ }^{114}$ this allows wavelengths of low luminous efficiency for the rod system to be transmitted to the eye, whilst those that have a higher luminous efficiency are absorbed by the filter. This results in a reduction in both disability and discomfort glare. Naturally, such lenses alter the relative spectral sensitivity function of the patient, so that they will report that red no longer appears so very dark. Recently, it has been suggested that blue cone monochromats benefit most from magenta tints. ${ }^{115}$ Patients with progressive cone dystrophy may also be aided by tinted lenses. ${ }^{116}$ The tint will depend on the dystrophy's effect on visual function: some patients, for example those with well-preserved colour vision and cone function, may be best served by neutral tints; others in the end stages of the disease may benefit from deep red tints in the same way as rod monochromats. Some caution should be exercised when fitting cone dystrophy patients with contact lenses. Because colour vision is poor (or absent), patients may be incapable of detecting conjunctival erythema by themselves. Additionally, the symptoms of some contact lens complications, such as photophobia resulting from corneal infiltration, could be masked by the symptoms of the dystrophy. Miotic drops may be used by patients with severe photophobia, but are rarely well tolerated.

\section{Conclusion}

The cone and cone-rod dystrophies comprise a heterogeneous group of disorders, each differing in their clinical features, underlying genetic mutation and visual prognosis. Great progress has been made in recent years in the understanding of the disease mechanisms underlying the cone dystrophies and it is likely that rapid advances in our knowledge of the progressive cone dystrophies in particular will develop, especially as the causative genetic mutations are identified. Previous research has concentrated on defining and classifying the clinical phenotype in order to guide the search for genetic mutations. The future emphasis will shift, as more genes responsible for causing cone dystrophy are identified, towards exploring the effects on retinal function of specific genetic mutations in human and experimental animal models. This will necessitate a collaboration between clinicians and scientists working in a variety of different disciplines, including molecular genetics, cell biology, psychophysics, electrophysiology and developmental biology. The real challenge remains in the identification and implementation of treatment methods that will improve or stabilise retinal function and prevent blindness. 
The authors would like to thank John Mollon and Benedict Regan for their comments on earlier versions of this text and the Wellcome and Cambridge Commonwealth Trusts for their financial support.

\section{References}

1. Theiss $\mathrm{P}$, Grusser $\mathrm{O}$. Vision and cognition in the natural philosophy of Albert the Great (Albertus Magnus). Doc Ophthalmol 1994;86(2):123-51.

2. Weleber RG, Eisner A. Cone degeneration ('bull's eye dystrophies') and colour vision defects. In: Newsome DA, editor. Retinal dystrophies and degenerations. New York: Raven Press, 1988:233-56.

3. Ruddock KH. Psychophysics of inherited colour vision deficiencies. In: Foster D, editor. Inherited and acquired colour vision deficiencies. Basingstoke: Macmillan Press, 1991:4-37.

4. Piantanida T. Genetics of inherited colour vision deficiencies. In: Foster D, editor. Inherited and acquired colour vision deficiencies. Basingstoke: Macmillan Press, 1991:88-114.

5. Nathans J, Sung CH, Weitz CJ, Davenport CM, Merbs SL, Wang Y. Visual pigments and inherited variation in human vision. Soc Gen Physiol Ser 1992;47:109-31.

6. Mollon JD. ' . . . aus dreyerley Arten von Membranen oder Molekülen': George Palmer's legacy. In: Cavonius CR, editor. Colour vision deficiencies XIII. Dordrecht: Kluwer, 1997:3-20.

7. Smith VC, Pokorny J. Cone dysfunction syndromes defined by colour vision. In: Verriest $G$, editor. Colour vision deficiencies V. Bristol: Adam Hilger, 1980:69-82.

8. Sharpe LT, Nordby K. The photoreceptors in the achromat. In: Hess RF, Sharpe LT, Nordby K, editors. Night vision. Cambridge: Cambridge University Press, 1990:335-82.

9. Krill AE, Deutman AF, Fishman M. The cone degenerations. Doc Ophthalmol 1973;35(1):1-80.

10. Andreasson S, Tornqvist K. Electroretinograms in patients with achromatopsia. Acta Ophthalmol (Copenh) 1991;69:711-6.

11. Larsen H. Demonstration microscopischer Prapärate von einem monochromatischen Auge. Klin Monatsbl Augenheilkd 1921;67:301-2.

12. Harrison R, Hoefnagel D, Hayward JN. Congenital total color blindness: a clinicopathological report. Arch Ophthalmol 1960;64:685-92.

13. Falls HF, Wolter JR, Alpern M. Typical total monochromacy: a histological and psychophysical study. Arch Ophthalmol 1965;74:610-6.

14. Glickstein M, Heath GG. Receptors in the monochromatic eye. Vision Res 1975;15:633-6.

15. Alpern M, Falls H, Lee GB. The enigma of typical total monochromacy. Am J Ophthalmol 1960;50:326-42.

16. Sloan LL, Newhall SM. Comparison of cases of atypical and typical achromatopsia. Am J Ophthalmol 1942;25:945-61.

17. Sloan LL. Congenital achromatopsia: a report of 19 cases. J Opt Soc Am 1954;44:117-28.

18. Blackwell HR, Blackwell OM. Rod and cone receptor mechanisms in typical and atypical achromatopsia. Vision Res 1961;1:62-107.

19. Auerbach E, Krikpke B. Achromatopsia with amblyopia. II. A psychophysical study of 5 cases. Doc Ophthalmol 1974;37(1):119-44.

20. Hecht S, Shlaer S, Smith EL, Haig C, Peskin JC. The visual functions of a completely colorblind person. Am J Physiol 1938;123:94-5.

21. Hecht S, Shlaer S, Smith EL, Haig C, Peskin JC. The visual functions of the complete colorblind. J Gen Physiol 1948;31:459-72.
22. Krastel $\mathrm{H}$, Jaeger $\mathrm{W}$. Large field spectral sensitivity in congenital and acquired achromatopsia. In: Verriest G, editor. Colour vision deficiencies VI. The Hague: Junk, 1982:329-32.

23. Arbour NC, Zlotogora J, Knowlton RG, Merin S, Rosenmann A, Kanis AB, et al. Homozygosity mapping of achromatopsia to chromosome 2 using DNA pooling. Hum Mol Genet 1997;6:689-94.

24. Pentao L, Lewis RA, Ledbetter DH, Patel PI, Lupski JR. Maternal uniparental isodisomy of chromosome 14: association with autosomal recessive rod monochromacy. Am J Hum Genet 1992;50:690-9.

25. Polland W, Nordstrom S. Eight cases of congenital achromatopsia with amblyopia in two pedigrees from Northern Sweden. Acta Ophthalmol (Copenh) 1979;57:653-64.

26. Nordstrom S, Polland W. Different expressions of one gene for congenital achromatopsia with amblyopia in Northern Sweden. Hum Hered 1980;30:122-8.

27. Pokorny J, Smith VC, Pinckers AJ, Cozijnsen M. Classification of complete and incomplete autosomal recessive achromatopsia. Graefes Arch Clin Exp Ophthalmol 1982;219:121-30.

28. Smith VC, Pokorny J, Newell FW. Autosomal recessive incomplete achromatopsia with protan luminosity. Ophthalmologica 1978;177:197-207.

29. Smith VC, Pokorny J, Newell FW. Autosomal recessive incomplete achromatopsia with deutan luminosity. Am J Ophthalmol 1979;87:393-402.

30. van Norren D, de Vries-de Mol EC. A case of incomplete achromatopsia of the deutan type. Doc Ophthalmol 1981;51:365-72.

31. Franceschetti A, Jaeger W, Klein D, Ohrt V, Rickli H. Etude pathophysiologique et génétique de la grande famille d'achromates de l'île de fur (Danemark) (Description d'une nouvelle famille avec achromatopsie totale chez le fils aîné et achromatopsie incomplete chez le frère cadet). XVIII Concilium Ophthalmologicum Belgica vol II, 1958;1582-8.

32. Waardenburg PJ. Achromatopsia congenita. In: Waardenburg PJ, Franceschetti A, Klein D, editors. Genetics and ophthalmology. Assen, The Netherlands: Royal van Gorkum, 1969:1696-718.

33. Gouras P, Mackay CJ, Lewis AL. The blue cone electroretinogram isolated in a sex-linked achromat. In: Drum B, Verriest G, editors. Colour vision deficiencies IX. Dordecht: Kluwer, 1989:89-93.

34. Alpern M, Lee GB, Maaseidvaag FL, Miller SS. Colour vision in blue cone monochromacy. J Physiol (Lond) 1971;212:211-33.

35. Reitner A, Sharpe L, Zrenner E. Is colour vision possible with only rods and blue-sensitive cones? Nature 1991;352:798-800.

36. Hansen E. Typical and atypical monochromacy studied by specific quantitative perimetry. Acta Ophthalmol (Copenh) 1979;57:211-24.

37. Berson EL, Sandberg MA, Rosner B, Sullivan PL. Color plates to help identify patients with blue cone monchromatism. Am J Ophthalmol 1983;95:741-7.

38. Pinckers A. Berson test for blue cone monochromatism. Int Ophthalmol 1992;16:185-6.

39. Smith VC, Pokorny J, Delleman JW, Cozijnsen M, Houtman WA, Went LN. X-linked incomplete achromatopsia with more than one class of functional cones. Invest Ophthalmol Vis Sci 1983;24:451-7.

40. Hess RF, Mullen KT, Sharpe LT, Zrenner E. The photoreceptors in atypical achromatopsia. J Physiol (Lond) 1989;417:123-49.

41. Pagon RA, Chatrian GE, Hamer RD, Lindberg KA. Heterozygote detection in $\mathrm{X}$-linked recessive incomplete achromatopsia. Ophthalmic Paediatr Genet 1988;9:43-56. 
42. Gottlob I, Reinecke R. Eye and head movements in patients with achromatopsia. Graefes Arch Clin Exp Ophthalmol 1994;232:392-401.

43. Nathans J, Davenport CM, Maumenee IH, Lewis RA, Hejtmancik JF, Litt M, et al. Molecular genetics of human blue cone monochromacy. Science 1989;245:831-8.

44. Kazmi MA, Sakmar TP, Ostrer H. Mutation of a conserved cysteine in the $\mathrm{X}$-linked cone opsins causes color vision deficiencies by disrupting protein folding and stability. Invest Ophthalmol Vis Sci 1997;38:1074-81.

45. Nathans J, Maumenee IH, Zrenner E, Sadowski B, Sharpe LT, Lewis RA, et al. Genetic heterogeneity among blue-cone monochromats. Am J Hum Genet 1993;53:987-1000.

46. Reyniers T, van Theinen MN, De Boulle K, Dvries K, Restelijn P, Willems PJ. Gene conversion between red and defective green opsin gene in blue cone monochromacy. Genomics 1995;29:323-8.

47. Ladekjaer-Mikkelsen AS, Rosenberg T, Jorgensen AL. A new mechanism in blue cone monochromatism. Hum Genet 1996;98:403-8.

48. Fleischman JA, O'Donnell FEJ. Congenital X-linked incomplete achromatopsia: evidence for slow progression, carrier fundus findings, and possible genetic linkage with glucose-6-phosphate dehydrogenase locus. Arch Ophthalmol 1981;99:468-72.

49. Francois J, Verriest G, Matton-van Leuven MT, De Rouck A, Manavian D. Atypical achromatopsia of sex-linked recessive inheritance. Am J Ophthalmol 1966;61:1101-8.

50. Pokorny J, Smith VC, Verriest G, Pinckers AJLG. Congenital and acquired color vision defects. New York: Grune and Stratton, 1979

51. Weale RA. Cone-monochromatism. J Physiol (Lond) 1953;113:115-22.

52. Fincham E. Defects of the colour-sense mechanism as indicated by the accommodation reflex. J Physiol (Lond) $1953 ; 121: 570-80$

53. Gibson IM. Visual mechanisms in a cone monochromat. J Physiol (Lond) 1962;162:P10-11.

54. Ikeda H, Ripps $H$. The electroretinogram of a cone monochromat. Arch Ophthalmol 1966;75:513-7.

55. Weale RA. Photo-sensitive reactions in foveae of normal and cone monochromatic observers. Optica Acta 1959;6:158-74

56. Pitt FHG. Monochromatism. Nature 1944;154:466-8.

57. Jaeger W. Genetics of congenital colour deficiencies. In: Jameson D, Hurvich LM, editors. Visual psychophysics. Berlin: Springer, 1972:626-42.

58. Alpern M. What is it that confines in a world without color? Invest Ophthalmol Vis Sci 1977;13:648-74.

59. Crone RA. Combined forms of congenital colour defects: a pedigree with atypical total colour blindness. Br J Ophthalmol 1956;40:462-72.

60. van Lith $G$. General cone dysfunction without achromatopsia. In: Verriest G, editor. Doc Ophthalmol Proc Ser X, ISCERG Symposium, Los Angeles, 1973:175-80.

61. Keunen JEE, DeBrabandere SRS, Liem ATA. Foveal densitometry and colour matching in oligocone trichromacy. In: Drum B, editor. Color vision deficiencies XII, 1995:202-3.

62. Neuhann T, Krastel H, Jaeger W. Differential diagnosis of typical and atypical congenital achromatopsia. Graefes Arch Clin Exp Ophthalmol 1978;209:19-28.

63. Jacobson DM, Thompson HS, Bartley JA. X-linked progressive cone dystrophy: clinical characteristics of affected males and female carriers. Ophthalmology 1989;96:885-95.

64. Birch DG, Anderson JL. Rod visual fields in cone-rod degeneration. Comparison to retinitis pigmentosa. Invest Ophthalmol Vis Sci 1990;31:2288-99.

65. Krauss HR, Heckenlively JR. Visual field changes in cone-rod dystrophy. Arch Ophthalmol 1982;100:1784-90.
66. Miyake Y, Shiroyama N, Sugita S, Horiguchi M, Yagasaki K Fundus albipunctatis associated with cone dystrophy. $\mathrm{Br} \mathrm{J}$ Ophthalmol 1992;76:375-9.

67. Heckenlively JR, Weleber RG. X-linked progressive cone dystrophy with tapetal-like sheen: a newly recognized entity with Mizuo-Nakamura phenomenon. Arch Ophthalmol 1986;104:1322-8.

68. Moore AT. Cone and cone-rod dystrophies. J Med Genet 1992;29:289-90.

69. Reichel E, Brue AM, Sandberg MA, Berson EL. An electroretinographic and molecular genetic study of cone degeneration. Am J Ophthalmol 1989;108:540-7.

70. Kellner U, Sadowski B, Zrenner E, Foerster MH. Selective cone dystrophy with protan genotype. Invest Ophthalmol Vis Sci 1995;36:2381-7.

71. van Everdingen JAM, Went LN, Keunen JEE, Oosterhuis JA. $X$ linked progressive cone dystrophy with specific attention to carrier detection. J Med Genet 1992;29:291-4.

72. Verriest G. Further studies on acquired deficiency of color discrimination. J Opt Soc Am 1963;53:185-95.

73. Marré M, Marré E, Zenker HJ, Fulle D. Color vision in a family with autosomal dominant cone dystrophy. In: Drum B, Verriest G, editors. Colour vision deficiencies IX Dordrecht: Kluwer, 1989:181-7.

74. Bresnick GH, Smith V, Pokorny J. A familial macular dystrophy with apparently preferential short-wavelengthsensitive cone involvement. Preliminary report. In: Drum B Verriest G, editors. Colour vision deficiencies IX. Dordecht Kluwer, 1989:195-200.

75. van Schooneveld MJ, Went LN, Oosterhuis JA. Dominant cone dystrophy starting with blue cone involvement. $\mathrm{Br} \mathrm{J}$ Ophthalmol 1991;75:332-6.

76. Went LN, van Schooneveld MJ, Oosterhuis JA. Late onset dominant cone dystrophy with early blue cone involvement. J Med Genet 1992;29:295-8.

77. Yagasaki K, Jacobson SG. Cone-rod dystrophy phenotypic diversity by retinal function testing. Arch Ophthalmol 1989;107:701-8

78. Pinckers A, Deutman AF. Peripheral cone disease. Ophthalmologica 1977;174:145-50.

79. Ripps H, Noble KG, Greenstein VC, Siegel IM, Carr RE. Progressive cone dystrophy. Ophthalmology 1987;94:1401-9.

80. Szlyk J, Fishman GA, Alexander KR, Peachy NS, Derlacki DJ. Clinical subtypes of cone-rod dystrophy. Arch Ophthalmol 1993;111:781-8.

81. Sadowski B, Zrenner E. Cone and rod function in cone degenerations. Vision Res 1997;37:2303-14.

82. Pearlman JT, Owen WG, Brounley DW, Sheppard JJ. Cone dystrophy with dominant inheritance. Am J Ophthalmol 1974;77:293-303.

83. Vaegan, Well GS. Well preserved photoreceptor and neural function in early cone/rod dystrophies: an initial abnormality in inner retina? Invest Ophthalmol Vis Sci 1991;32(Suppl):1138.

84. Gouras P, Eggars HM, MacKay CJ. Cone dystrophy, nyctalopia and supernormal rod responses: new retinal degeneration. Arch Ophthalmol 1983;101:718-24.

85. Alexander KR, Fishman GA. Supernormal scotopic ERG in cone dystrophy. Br J Ophthalmol 1984;68:69-78.

86. Fujii N, Shiono T, Wada Y, Nakazawa M, Tamai M, Yamada N. Autosomal dominant cone-rod dystrophy with negative electroretinogram. Br J Ophthalmol 1995;79:916-21.

87. Kellner U, Foerster MH. Cone dystrophies with negative photopic electroretinogram. Br J Ophthalmol 1993;77:404-9.

88. Meire F, Bergan AA, De Rouck A, Leys M, Delleman JW. X linked progressive cone dystrophy: localisation of the gene locus to Xp21-p11.1 by linkage analysis. Br J Ophthalmol 1994;78:103-8.

89. Verdoorn C, Pinckers AJLG. X-linked cone dystrophy. Doc Ophthalmol 1988;70:195-8. 
90. Hong HK, Ferrell RE, Gorin MB. Clinical diversity and chromosomal localization of X-linked cone dystrophy (COD1). Am J Hum Genet 1994;55:1173-81.

91. Bergen AA, Pinckers AJ. Localization of a novel X-linked progressive cone dystrophy to $\mathrm{Xq} 27$ : evidence for genetic heterogeneity. Am J Hum Genet 1997;60:1468-73.

92. Pinckers AJLG, Timmerman GJMEN. Sex difference in progressive cone dystrophy I. Ophthalmic Paediatr Genet 1981;1:17-23.

93. Gregory CY, Evans K, Whittaker JL, Fryer A, Weissenbach J, Bhattacharya SS. Refinement of the cone-rod retinal dystrophy locus on chromosome 19q [letter]. Am J Hum Genet 1994;55:1061-3.

94. Evans K, Fryer A, Inglehearn C, Duvall-Young J, Whittaker JL, Gregory CY, et al. Genetic linkage of cone-rod retinal dystrophy to chromosome $19 \mathrm{q}$ and evidence for segregation distortion. Nature Genet 1994;6:210-31.

95. Evans K, Duvall-Young J, Fitzke FW, Arden GB, Bhattacharya SS, Bird AC. Chromosome 19q cone-rod retinal dystrophy: ocular phenotype. Arch Ophthalmol 1995;113:195-201.

96. Kellsell RE, Evans K, Gregory CY, Moore AT, Bird AT, Hunt $D M$. Localisation of a gene for dominant cone-rod dystrophy (CORD6) to chromosome 17p. Hum Mol Genet 1997;6:597-600.

97. Jacobson SG, Kemp CM, Cideciyan A, Sun XK, Vandenburgh K, Sheffield VC, et al. Spectrum of functional phenotypes in $r d s$ mutations [abstract]. Invest Ophthalmol Vis Sci 1994;35:1044.

98. Nakazawa M, Kikawa E, Chida Y, Wada Y, Shiono T, Tamai M. Autosomal dominant cone-rod dystrophy associated with mutations in codon 244 (Asn244His) and codon 184 (Tyr184Ser) of the peripherin/ RDS gene. Arch Ophthalmol 1996;114:72-81.

99. Nakazawa M, Naoi N, Wada Y, Nakazaki S, Maruiwa F, Sawada A, et al. Autosomal dominant cone-rod dystrophy associated with a Val200Glu mutation of the peripherin/ RDS gene. Retina 1996;16:405-10.

100. Fishman GA, Stone EM, Alexander KR, Gilbert LD, Derlacki DJ, Butler NS. Serine-27-phenylalanine mutation within the peripherin/RDS gene in a family with cone dystrophy. Ophthalmology 1997;104:299-306.

101. Warburg M, Sjo O, Tranebjaerg L, Fledelius H. Deletion mapping of a retinal cone-rod dystrophy: assignment to 18q211. Am J Med Genet 1991;39:288-93.

102. Klystra JA, Aylesworth AJ. Cone-rod retinal dystrophy in a patient with neurofibromatosis type 1 . Can J Ophthalmol 1993;28:79-80.

103. Balciuniene J, Johansson K, Sandgren O, Wachmeister L, Holmgren G, Forsman K. A gene for autosomal dominant progressive cone dystrophy (CORD5) maps to chromosome 17p12-p13. Genomics 1995;30:281-6.

104. Small KW, Syrquin M, Mullen L, Gehrs K. Mapping of autosomal dominant cone degeneration to chromosome 17p. Am J Ophthalmol 1996;121:13-8.

105. Payne AM, Downes SM, Bessant DAR, Taylor R, Holder GE, Warren MJ, et al. A mutation in guanylate cyclase activator 1A (GUCA1A) in autosomal dominant cone dystrophy mapping to a new locus on chromosome 6p21.1. Hum Mol Genet 1998;7:273-7.

106. Freund CL, Gregory-Evans CY, Furukawa T, Papaioannou $\mathrm{M}$, Looser J, Ploder L, et al. Cone-rod dystrophy due to mutations in a novel photoreceptor-specific homeobox gene (CRX) essential for maintenance of the photoreceptor. Cell 1997;91:543-53.

107. Kelsell RE, Yang RB, Gregory-Evans K, Payne AM, Kaplan J, Garbers DL, et al. Dominant cone-rod dystrophy caused by mutations of the guanylate cyclase (RETCG1) gene. Nature Genet 1998;in press.
108. Kikawa E, Nakazawa M, Chida Y, Shiono T, Tamai M. A novel mutation (Asn244Lys) in the peripherin/RDS gene causing autosomal dominant retinitis pigmentosa associated with bull's-eye maculopathy detected by nonradioisotopic SSCP. Genomics 1994;20:137-9.

109. Perrault I, Rozet JM, Calvas P, Gerber S, Camuzat A, Dollfus $\mathrm{H}$, et al. Retinal-specific guanylate cyclase gene mutations in Leber's congenital amaurosis. Nature Genet 1996;14:461-4.

110. Kwitek-Black AE, Carmi R, Duyk GM, Buetow KH, Elbedour K, Parvari R, et al. Linkage of Bardet-Biedl syndrome to chromosome $16 \mathrm{q}$ and evidence for non-allelic genetic heterogeneity. Nature Genet 1993;5:392-6.

111. Leppert M, Baird L, Anderson KL, Otterud B, Lupski JR, Lewis RA. Bardet-Biedl syndrome is linked to DNA markers on chromosome $11 \mathrm{q}$ and is genetically heterogeneous. Nature Genet 1994;7:108-12.

112. Sheffield VC, Carmi R, Kwitek-Black A, Rokhlina T, Nishimura D, Duyk GM, et al. Identification of a Bardet-Biedl syndrome locus on chromosome 3 and evaluation of an efficient approach to homozygosity mapping. Hum Mol Genet 1994;3:1331-5.

113. Carmi R, Elbedour K, Stone EM, Sheffield VC. Phenotypic differences among patients with Bardet-Biedl syndrome linked to three different chromosome loci. Am J Med Genet 1995;59:199-203.

114. Terry RL. The use of tinted contact lenses in a case of congenital rod monochromatism. Clin Exp Optom 1988;71:188-90.

115. Haegerstrom-Portnoy G, Schneck M, Verdon W, Hewletts S. Clinical vision characteristics of the congenital achromatopsias. II. Color vision. Optom Vis Sci 1996;73:457-65.

116. Zisman F, Harris MG. Filter enhanced visual acuity in a case of central cone-rod dystrophy. In: Drum B, Verriest G, editors. Colour vision deficiencies IX. Dordecht: Kluwer, 1989:189-95.

117. Nathans J, Piatanida TP, Eddy RL, Shows TB, Hogness DS. Molecular genetics of inherited variations in human colour vision. Science 1986;232:203-10.

118. Tranebjaberg L, Sjo O, Warburg M. Retinal cone dysfunction associated with a de novo balanced translocation. 1;6(q44;q27). Ophthalmic Paediatr Genet 1986;7:167-73.

119. Weitz CJ, Miyake Y, Shinazato K, Montag E, Zrenner E, Went LN, et al. Human tritanopia associated with two amino acid substitutions in the blue-sensitive opsin. Am J Hum Genet 1992;50:498-507.

120. Weitz CJ, Went LN, Nathans J. Human tritanopia associated with a third amino acid substitution in the blue sensitive visual pigment. Am J Hum Genet 1992;51:444-6.

121. Michaud JL, Heon E, Guilbert F, Weill J, Puech B, Benson L, et al. Natural history of Alstrom syndrome in early childhood: onset with dilated cardiomyopathy. J Pediatr 1996;128:225-9.

122. Bjork $U$, Lindblom $U$, Wadensten L. Retinal degeneration in hereditary ataxia. J Neurol Neurosurg Psychiatry 1956;19:186-93.

123. Jalili IK, Smith NJ. A progressive cone-rod dystrophy and amelogenesis imperfecta: a new syndrome. J Med Genet 1988;25:738-40.

124. Russell-Eggitt IM, Taylor DS, Clayton PT, Garner A, Kriss A, Taylor JF. Leber's congenital amaurosis: a new syndrome with a cardiomyopathy. Br J Ophthalmol 1989;73:250-4.

125. Hansen E, Froyshov-Larsen I, Berg K. A familial syndrome of progressive cone dystrophy, degenerative liver disease, endocrine dysfunction and hearing defect: ophthalmological findings. Acta Ophthalmol (Copenh) 1976;54:129-44.

126. Jalili IK. Cone-rod congenital amaurosis associated with congenital hypertrichosis: an autosomal recessive condition. J Med Genet 1989;26:504-10. 